\title{
The Public Authority of the International Tribunal for the Law of the Sea
}

Lan Ngoc Nguyen"

\section{Introdruction}

The 1982 United Nations Convention on the Law of the Sea (UNCLOS" or "the Convention") establishes a system for dispute settlement which constitutes an integral part of the Convention. ${ }^{1}$ As part of this system, States decided to establish a new, permanent tribunal specializing in law of the sea disputes, called the International Tribunal for the Law of the Sea ("ITLOS" or "the Tribunal"). The reason behind the creation of this new tribunal, alongside the International Court of Justice (ICJ) which had been the main forum for law of the sea disputes until then, was the high level of dissatisfaction on the part of many developing States with the ICJ following some of its controversial judgments. ${ }^{2}$ In other words, ITLOS came about as a demonstration of developing countries' rejection of the ICJ's authority. ITLOS was expected to be less conservative than the ICJ, more representative of various legal systems and the different regions of the world, as well as more accessible to non-State actors. ${ }^{3}$ As such, ITLOS was a timely response to the transformation of international society through globalization. ${ }^{4}$ The rationale behind the establishment of ITLOS and the fact that it is a permanent and specialized tribunal thus suggest that the Tribunal would become the judicial authority in the field of the law of the sea.

* Assistant Professor of Public International Law, Faculty of Law, Economics and Governance, Utrecht University.

1 United Nations Convention on the Law of the Sea, Dec. 10, 1982, 1833 UNTS 396.

2 See, e.g., South West Africa (Ethiopia and Liberia v. South Africa), Second Phase, Judgment, ICJ Reports 1966, 6.

3 See, e.g., the statements of El Salvador, Cyprus, Peru, Zaire, Tunisia, Fiji in the Plenary during the fourth session (1976). Virginia Commentary, Volume V, 42.

4 Caminos, H. (2009), "The Creation of the International Tribunal for the Law of the Sea as a Specialized Court" In: A. Constantinides and N. Zaikos (eds), The Diversity of International Law: Essays in Honour of Professor Kalliopi K. Koufa. Leiden/Boston: Martinus Nijhoff, 97-108. 
However, after ITLOS was established, it immediately met with considerable scepticism, notably regarding the redundancy and contribution to the problem of international law. ${ }^{5}$ While these criticisms were certainly not endorsed by all, ${ }^{6}$ they signalled that from the very beginning, not only the existence of ITLOS but also its potential to exert any authority was cast into doubt. Moreover, after more than twenty years existence, the fact that ITLOS docket comprises only 24 cases and two advisory opinion requests has spurred criticism that ITLOS is heavily underutilized. In fact, ITLOS is constantly in competition with the ICJ and ad hoc arbitral tribunals for cases. Despite being the specialized court for the law of the sea, many States still refer their cases to the latter two. This could partly be explained by the fact that Annex VII arbitration, not ITLOS, is the default forum under UNCLOS. ${ }^{7}$ However, as the new standing court for the law of the sea, ITLOS's lack of activity may be an indication of a sense of mistrust on the part of the State parties of the Tribunal's competence and calls into question the Tribunal's authority in resolving disputes and developing the law of the sea in general.

Against this background, this paper seeks to examine ITLOS' exercise of public authority in the field of the law of the sea, by exploring whether ITLOS has been able to exercise public authority and if so, in what ways. In order to do so, the paper will use the conceptual framework developed by von Bogdandy and Venzke in their book In Whose Name? A Public Law Theory of International Adjudication. The departure point for analysis is the conception of public authority described by the authors as "the capacity, based on legal acts, to impact other actors in their exercise of freedom, be it legally or simply de facto" ${ }^{8}$. In particular, von Bogdandy and Venzke contend that there are two ways in which international courts and tribunals

5 See, e.g., Oda, S. (1995), "Dispute settlement prospects in the Law of the Sea", International and Comparative Law Quarterly 44(4), 863-872.

6 See, e.g., Treves, T. (2000), "New Trends in the Settlement of Disputes and the Law of the Sea Convention" In: H.N. Scheiber (ed.), Law of the Sea: The Common Heritage and Emerging Challenges. The Hague/Boston: Kluwer, 61-86; Charney, J. (1998), "Is international law threatened by multiple international tribunals?", Collected Courses of the Hague Academy of International Law 271, available at https://refe renceworks.brillonline.com/entries/the-hague-academy-collected-courses/"*A978904 1112101_03, accessed 27 December 2017.

7 Annex VII arbitration is deemed to have been accepted either when States have not declared their preferred choice or forum (Article 287(3)) or when they have not accepted the same forum (Article 287(5)).

8 Von Bogdandy, A. and Venzke, I. (2014), In Whose Name? A Public Law Theory of International Adjudication. Oxford: Oxford University Press. 
exercise public authority: one in the decision vis-à-vis the state at the losing end of a case $\mathrm{e}^{9}$ and two, in the ability to establish interpretation as points of reference for the legal discourse beyond legal bindingness in a single case. The latter is determined by looking at the power of precedents, specifically the legitimizing effect of precedents. As von Bogdandy and Venzke further argue, the exercise of public authority by international courts and tribunals transpires through judicial law-making, but in that process, "courts depend on a suitable case being brought to them" ${ }^{10}$. Accordingly, based on the analysis of the cases that have been decided by ITLOS to date, this paper will examine the two abovementioned elements of public authority in the particular context of ITLOS in order to understand whether and to what extent they manifest themselves in the Tribunal's operation. As space does not allow for a detailed examination of each and every case, the paper will proceed to analyse ITLOS' decisions according to the types of proceeding which fall under the Tribunal's jurisdiction, namely prompt release proceedings, provisional measures, contentious cases and advisory opinions.

\section{ITLOS' Exercise Of Public Authority}

\section{Prompt release proceedings}

Coastal States have the right to arrest a vessel alleged to have violated their laws and regulations on the exploitation and conservation of living resources under Article 73(1) UNCLOS. However, after the flag State of the detained vessel has posted a reasonable bond or other security, the coastal State has the obligation to release the vessel and the crew under Article 73(2). Should the coastal State fail to do so, the flag State may initiate a prompt release proceedings pursuant to Article 292 UNCLOS. Prompt release proceedings thus essentially revolve around whether the bond that has been posted is "reasonable". The Convention, however, provides no guidance for the interpretation of "reasonable bond".

In $M / V$ Saiga, the first case in which ITLOS assessed the reasonableness of a bond, it only stated in a general manner that "the criterion of reasonableness encompasses the amount, the nature and the form of the bond or financial security. The overall balance of the amount, form and nature of

9 Ibid., 114.

10 Ibid., 109. 
bond or financial security must be reasonable."11 Then in Camouco, ITLOS for the first time provided a list of factors relevant in an assessment of the reasonableness of bonds or other financial security, ${ }^{12}$ which included the gravity of the alleged offences, the penalties imposed or imposable under the laws of the detaining State, the value of the detained vessel and of the cargo seized, the amount of the bond imposed by the detaining State and its form. ${ }^{13}$ The list of factors relevant for the determination of reasonable bond in Camouco was later adopted in Monte Confurco. ${ }^{14}$ In determining the reasonable bond, it is evident that ITLOS was only occupied with the gravity of the offence committed by the vessel, by reference to the penalties imposed or imposable under the law of the detaining State. ${ }^{15}$ It was not until the Hoshinmaru case that ITLOS took note of conservation concerns in the wider context of widespread illegal fishing in order to properly assess the gravity of the offence.

In conclusion, even though the term "reasonable bond" was deliberately left open by UNCLOS drafters, the consolidated factors emerging from ITLOS prompt release judgments have filled this void and provided some guidance as to how reasonableness is to be determined. ITLOS progressed from setting out general criteria in the first case to elaborating on more specific criteria for determining the reasonableness of the bond, while endeavouring to balance predictability and flexibility in its assessment of reasonableness. ${ }^{16}$ As a consequence, ITLOS provided much-needed clarity to the term reasonable bond - a key term in prompt release proceedings. The criteria that ITLOS developed to assess what constitutes "reasonable bond" are perhaps the most visible contribution that ITLOS has made to developing UNCLOS, thus providing important guidance to States in exercising their rights and obligations under the Convention.

It can also be seen that ITLOS strived to build on its own case law. Even when ITLOS gradually incorporated non-quantitative elements in the assessment of reasonable bond, it still endeavoured to ground its analysis

11 M/V Saiga M/V "SAIGA" (Saint Vincent and the Grenadines v. Guinea) (Prompt Release, Judgment) ITLOS Reports 1997, 6 para. 82.

12 Camouco (Panama v. France) (Prompt Release, Judgment) ITLOS Reports 2000, para. 10.

13 Ibid., para. 67.

14 Monte Confurco (Seychelles v. France) (Prompt Release, Judgment) ITLOS Reports 2000, para. 86.

15 Ibid., para. 89.

16 Türk, H. (2012), "The Work of the International Tribunal for the Law of the Sea", Ocean Yearbook Online 26(1), 181-208. 
on the list of factors drawn up in the first cases. In doing so, ITLOS has developed a coherent body of case law which becomes the reference point for prompt release proceedings under UNCLOS. It is interesting to note that since 2007, ITLOS has not received any requests for prompt release. This is a great contrast to the first ten years of its existence when the majority of cases in its docket were prompt release cases. It is not exactly certain why this is the case, but one can speculate that the consolidated criteria for determining the bond as established in ITLOS case law have provided useful guidance for both the coastal State and flag State to deal with prompt release cases out of court. This, in turn, confirms that ITLOS' authority transcends the courtroom, and in the context of prompt release procedures, ITLOS' judgments arguably have a legitimising impact on the behaviour of States.

\section{Provisional measures}

Similar to several other courts and tribunals, ITLOS has the power to order provisional measures under Article 290 UNCLOS. Admittedly, due to the nature of provisional measures proceedings, the extent to which ITLOS could engage in a detailed exposition of substantive legal issues is limited. However, it is argued that ITLOS' provisional measures cases still provide useful material to examine ITLOS' public authority vis-à-vis the parties to the case. This is due to the unique competence conferred upon ITLOS with regard to provisional measures. First, Article 290(5) allows the parties which initiated a case before an Annex VII arbitral tribunal to, pending the institution of the arbitral tribunal, request ITLOS to prescribe provisional measures. In other words, ITLOS has the competence to prescribe provisional measures in a case whose merits will be heard in another forum. This means that the measures it prescribes will be addressed to parties which have not accepted its jurisdiction in respect of the dispute. ${ }^{17}$ The arbitral tribunal, in turn, has the power to revoke the provisional measures prescribed by ITLOS. Second, under Article 89(5) of the Rules of the Tribunal, ITLOS has power to prescribe provisional measures that differ from those requested by the parties. Taken together, this means that there is no guarantee that ITLOS' provisional measures will be accepted by States,

17 Mensah, T.A. (2002), "Provisional Measures in the International Tribunal for the Law of the Sea (ITLOS)", Zeitschrift für ausländisches öffentliches Recht und Völkerrecht 62, 43-54, 46. 
unless the parties acknowledge the Tribunal's authority and act accordingly. The remainder of this part will thus be devoted to exploring whether ITLOS' provisional measures had any impact on the parties to the case.

ITLOS has to date issued six provisional measures orders, all with different natures from the restriction of fish catch in Southern Bluefin Tuna, the cooperation and consultation in MOX Plant, the establishment of expert groups in Land Reclamation, to the release of vessel and crew in ARA Libertad and Arctic Sunrise, and the suspension of domestic judicial proceedings in Enrica Lexie. In all but one of these orders, the parties complied with and gave effect to the measures prescribed by the Tribunal.

In fact, for four of them, namely Southern Bluefin Tuna, MOX Plant, Land Reclamation and ARA Libertad, ITLOS' provisional measure played a significant role in resolving the disputes, as the respective arbitral tribunals that were established did not, for various reasons, render an award in the merits phase in the end. For example, in MOX Plant, the fact that ITLOS' provisional measure was directed at both parties, instead of only at the Respondent as requested by the Applicant, proved instrumental in pushing the parties to reach a subsequent agreement on a wide range of measures, and improve bilateral co-operation on civil nuclear matters by the time the case was withdrawn by Ireland. ${ }^{18}$ In Land Reclamation, ITLOS ordered the establishment of a group of independent experts with the mandate to conduct a study on the effects of Singapore's land reclamation and to propose measures to deal with any adverse effects of such land reclamation. ${ }^{19}$ While this was not the measure that it requested, Malaysia still proceeded to set up a group of experts with Singapore as instructed. The parties were able to subsequently reach an agreement based on the work of the Group of Experts and did not proceed with arbitration. ${ }^{20}$ The provisional measure ordered by ITLOS was thus key in the settlement of the dispute between the two parties. ${ }^{21}$ Even when the provisional measure is subsequently revoked as in the case of Southern Bluefin Tuna because the Annex VII arbi-

18 Remarks by Ms Jill Barrett at Workshop "ITLOS At 20: Impacts of the International Tribunal for the Law of the Sea" (London, 23 May 2016), available at https:/ /www.lcilp.org/wp-content/uploads/2017/06/ITLOS-at-20-Event-Report.pdf, accessed 27 December 2017.

19 Land Reclamation in and around the Straits of Johor (Malaysia v. Singapore) (Provisional Measures, Order of 8 October 2003) ITLOS Reports 2003, 10 para. 106.

20 Case Concerning Land Reclamation by Singapore in and around the Straits of Johor (Malaysia v. Singapore) Award on Agreed Terms, para. 19, available at http://www. pca-cpa.org/MASI\%20Awardb1ca.pdf?fil_id=364.

21 Ibid., para. 21. 
tral tribunal found that it did not have jurisdiction to hear the case, both the arbitral tribunal and the parties were highly appreciative of ITLOS' provisional measures. Australia, for example, acknowledged that "the ITLOS Order already had played a significant role in encouraging the Parties to make progress on the issue of third-party fishing" 22 .

The only provisional measure which was rejected by one of the parties is the Arctic Sunrise case. Russia refused to appear before ITLOS and also refused to comply with the request of ITLOS to immediately release the Arctic Sunrise and allow the non-Russian crew members to leave the country. What is noteworthy, however, is that despite the rhetoric of rejecting ITLOS' authority, Russia eventually implemented the measures prescribed by ITLOS. Even though the authorities released the vessel and the crew pursuant to domestic legislation and no mention was made to ITLOS' order, ${ }^{23}$ the ultimate effect was the same.

In conclusion, the abovementioned provisional measures orders illustrate ITLOS' capacity to impact other actors, in this case, the parties to the case in their exercise of freedom. Even when the measures prescribed were not requested by either party or revoked, States were still willing to accept them and respect the authority of ITLOS. In this sense, as defined by Bogdandy and Venzke, ITLOS has managed to build its authority vis-à-vis the parties to the case. Some authors have criticized the fact that ITLOS' authority is only limited to provisional measures proceedings - and prompt release proceedings for that matter - making it more of a first instance court rather than a specialized body for law of the sea disputes. ${ }^{24}$ Such critiques are to a certain extent true. However, that does not mean that within these types of proceedings, ITLOS does not exercise authority. ITLOS, when dealing with provisional measures proceedings, has proven that it can have a significant impact on the conduct of the parties, and thus exercises its public authority over these States.

22 Southern Bluefin Tuna Case (Australia and New Zealand v. Japan), Award on Jurisdiction and Admissibility (4 August 2000) 39 ILM 1359, para. 69.

23 "Russia Releases Greenpeace's Arctic Sunrise Ship", The Moscow Times, 6 June 2014, available at https://www.themoscowtimes.com/2014/06/06/russia-releases-gr eenpeaces-arctic-sunrise-ship-a36246?, accessed 27 December 2017.

24 Rah, S. and Wallrabenstein, T. (2006), "Sustainability Needs Judicial Support: What Does ITLOS Offer in This Respect" In: P. Ehlers and R. Lagoni (eds), International Maritime Organisations and Their Contribution Towards a Sustainable Marine Development. Hamburg: LIT Verlag, 285-315. 


\section{Contentious cases}

ITLOS has only decided five contentious cases to date. ${ }^{25}$ Quantitatively speaking, five cases in twenty years of its existence is rather low and the criticism usually heard during the Tribunal's early days regarding its redundancy may thus seem to have some merits. The low number of cases also suggests that the extent to which ITLOS could exercise public authority is limited. After all, if there is no precedent generated in the first place, how can one speak of the power or impact of precedents? However, assessing the extent of public authority based solely on the number of judgments rendered would arguably be mistaken. First, it should be noted that the compliance rate for the judgments rendered by ITLOS is relatively high. A recent study shows that an overwhelming majority of the decisions by UNCLOS dispute settlement bodies have been implemented by parties to the case, including those that are considered super powers at the losing end of the cases. It follows, therefore, ITLOS has authority of the States. ${ }^{26}$ Second, in terms of authority in providing legal guidance, the important question to be asked is whether ITLOS has been able to provide authoritative interpretation in the limited number of cases that it has heard, and whether the Tribunal's decisions have become or have the potential to become points of reference for the legal discourse. In other words, the focus should be on the quality of the decision, particularly on whether ITLOS has made an impact beyond the cases decided and on whether the Tribunal's reasoning and decisions may "create legitimate expectations and must therefore be taken into account in future decisions" 27 .

$25 M / V$ "SAIGA" (No. 2) (Saint Vincent and the Grenadines v. Guinea), Judgment, ITLOS Reports 1999, para. 10; Delimitation of the maritime boundary in the Bay of Bengal (Bangladesh/Myanmar), Judgment, ITLOS Reports 2012, para. 4; M/V "Virginia G” (Panama/Guinea-Bissau), Judgment, ITLOS Reports 2014, para. 4; Dispute Concerning Delimitation of the Maritime Boundary between Ghana and Côte d'Ivoire in the Atlantic Ocean (Ghana/Côte d'Ivoire), Judgment, 23 September 2017; M/V "Norstar" (Panama v. Italy), Judgment, 10 April 2019. The $M / V$ "Louisa" case was also brought before ITLOS as a contentious case. However, the Tribunal found that it lacked jurisdiction and thus did not hear the merits of the case. See $M / V$ "Louisa" (Saint Vincent and the Grenadines v. Kingdom of Spain), Judgment, ITLOS Reports 2013, para. 4.

26 Duy Phan, H. (2019), "International Courts and State Compliance: An Investigation of the Law of the Sea Cases", Ocean Development \& International Law 50(1), 70-90.

27 Van Bogdandy and Venzke, supra note 8, 116. 
The role of international courts in the development of the law is "interstitial", meaning that the court "stands between the past and the future" 28 . Thus it is difficult, even impossible, to fully appreciate the impact of a court or tribunal's decision without the benefit of hindsight in light of later developments. In other words, a certain amount of time ought to elapse before any definitive conclusion could be drawn with respect to the impact of a judicial decision on the legal discourse or on States' behaviour. ${ }^{29}$ For a relatively young tribunal such as ITLOS and given the relatively low number of cases, this may prove difficult. However, it is argued that an assessment of the impact of a judicial decision, albeit only preliminarily, could still be made based on the quality of the judicial decisions, in which due attention should be paid to the legal reasoning as much as the result. This paper thus agrees with the analysis on the important role that judicial reasoning plays in assessing the authority of international courts and tribunals, particularly in their judicial law-making role, as elaborated in Bogdandy and Venzke's book. The persuasiveness of the legal reasoning provides a useful, even if inconclusive, indicator of the potential impact of judicial decisions in the longer term. Accordingly, the remainder of this section will examine two cases in which ITLOS's judgments are considered to be of particular importance in developing the law of the sea. As explained, it will not only examine the decisions that ITLOS reached, but also the cogency of legal reasoning.

\section{a. Virginia $G$}

ITLOS in Virginia $G$ engaged in a detailed examination of coastal States' regulatory and enforcement power in the exclusive economic zone (EEZ). ${ }^{30}$ In this case, ITLOS was faced with the question of whether a coastal State may regulate the bunkering of fishing vessels in the EEZ

28 Venzke, I. (2011), “The Role of International Courts as Interpreters and Developers of the Law: Working out the Jurisgenerative Practice of Interpretation”, Loyola Los Angeles International and Comparative Law Journal 34(1), 99-131,121.

29 Most of the assessment of the contributions of the PCIJ and the ICJ, for instance, is based on decades-old decisions, which allows the authors to track whether the Court's pronouncements have been accepted by States and other actors, and subsequently incorporated into formal sources of law. See Tams, C.J. and Sloan, J. (2013), The Development of International law by the International Court of Justice. Oxford: Oxford University Press.

30 M/V "Virginia G" (Panama/Guinea-Bissau), Judgment, ITLOS Reports 2014, para. 4. 
under its fisheries laws and regulations. This activity is not explicitly listed under Article 62(4) as one which the coastal State may regulate. Given the prevalence of offshore bunkering activities and their economic benefits, ${ }^{31} \mathrm{a}$ definitive answer to legal nature of the activity was highly needed. In Virginia G, ITLOS established a connection between Article 56(1) and 62(4) and further noted that the wording of Article 62(4) of the Convention, in particular, the use of "inter alia", indicated that this list is not exhaustive. ${ }^{32}$ In order for an activity to fall under Article 62(4), ITLOS determined that there must be a direct connection to fishing. ITLOS then observed that such a connection to fishing existed for the bunkering of foreign vessels fishing in the EEZ, since this enables fishing vessels to continue their activities without interruption at sea. ${ }^{33}$ For the above reasons, ITLOS concluded that coastal States may regulate the bunkering of foreign vessels fishing in its EEZ to conserve and manage its living resources under Article 56 of the Convention read together with Article 62(4) of the Convention. ${ }^{34}$

Turning to coastal States' enforcement power, in order for coastal States to ensure compliance with their laws and regulations on fisheries, Article 73(1) lists several measures permitting them to deal with foreign vessels illegally fishing in the EEZ, such as boarding, inspection, arrest and judicial proceedings. On the other hand, Article 73(3) prohibits imprisonment or any other form of corporal punishment as penalties for violations of fisheries laws and regulations. This leaves open the question as to whether a coastal State is allowed to take a measure which is not specified in Article 73(1) but also not prohibited under Article 73(3). Confiscation was one prominent example in ITLOS' cases, however, it was, again, only in Virginia $G$ that the ITLOS was able to substantively deal with the legality or otherwise of this measure. ${ }^{35}$

31 See Lagoni, R. (2007), "Offshore bunkering in the Exclusive Economic Zone" In: T.M. Ndiaye and R. Wolfrum (eds), Law of the Sea, Environmental Law and Settlement of Disputes: Liber amicorum Judge Thomas A. Mensah. Leiden: Brill/Nijhoff, 613-627, 614; M/V "SAIGA" (No. 2) (Saint Vincent and the Grenadines v. Guinea), Separate Opinion of Judge Anderson, para. 137; M/V "Virginia G" (Panamal Guinea-Bissau), Dissenting Opinion of Judge Ndiaye, paras 258-270.

32 Ibid., para. 213.

33 Ibid., para. 215.

34 Ibid., para. 217.

35 The issue of whether coastal State could legitimately confiscate foreign fishing vessels to ensure compliance with its fisheries law came up in three cases, namely in Grand Prince, Tomimaru and Virginia G. The first two were prompt release cases, thus ITLOS did not deal with the question in much detail. 
ITLOS first established whether (i) the legislation promulgated by Guinea-Bissau for the EEZ was in conformity with the Convention and (ii) whether the measures taken in implementing this legislation were necessary to ensure the compliance with the law and regulations adopted by the Coastal State. ${ }^{36}$ In answering the first question, ITLOS held that a law providing for the confiscation of a vessel offering bunkering services to foreign vessels fishing in the EEZ of Guinea-Bissau was not per se in violation of Article 73(1) of the Convention. Whether or not confiscation was justified in a given case depended on the facts and circumstances. ${ }^{37}$ For the second question, ITLOS determined that "the breach of the obligation to obtain written authorization for bunkering and to pay the prescribed fee was a serious violation" but that it was the result of "a misinterpretation of the correspondence" between the fishing vessels and the authorities of GuineaBissau. ${ }^{38}$ Therefore, ITLOS found that the confiscation of the vessel and the gas oil on board "was not necessary either to sanction the violation committed or to deter the vessels or their operators from repeating this violation" 39 .

Virginia $G$ was the first case in which ITLOS engaged in the interpretation of Article 73(1) which determines the scope of coastal States' enforcement power in the EEZ. What ITLOS managed to make clear was that confiscation is not a measure that is per inconsistent with Article 73, and that coastal States are permitted to take measures which are not explicitly mentioned in Article 73(1). However, the most crucial term in Article 73(1) was arguably "necessary" as this would determine whether the measure was consistent with UNCLOS. ITLOS, however, did not explain what was meant by "necessary"; instead, it only determined the gravity of the offence in question then compared it with the penalty imposed by the coastal State. Compared with how the term "necessary" has been interpreted by other international courts, ${ }^{40}$ ITLOS' necessity test was overly simplistic and rather arbitrary as it lacked an objective, guiding principle concerning the

36 Virginia G, supra note 30, para. 256.

37 Ibid., para. 257.

38 Ibid., para. 269.

39 Ibid.

40 See, for example, WTO Appellate Body's necessity test under Article XX(b) GATT or Article XIV(a) GATS in Appellate Body Report, Korea-Measures Affecting Imports of Fresh, Chilled and Frozen Beef, WT/DS161,169/AB/R (Dec. 11, 2000); Appellate Body Report, European Communities-Measures Affecting Asbestos and Asbestos-Containing Products, WT/DS135/R (Mar. 12, 2001); Appellate Body Report, United States - Measures Affecting Cross-Border Supply of Gambling and Betting Services WT/ DS285/AB/R (Apr. 7, 2005). 
interpretation of the term "necessary". A case-specific answer, unaccompanied by sound reasoning and clear guidance would make it difficult for coastal States to grasp the exact extent of the enforcement power granted to them in conserving fisheries resources, thus restricting the broader impact of ITLOS' decision, and thus ITLOS' authority in this regard.

\section{b. Bangladesh/Myanmar}

Bangladesh/Myanmar was the first case in which an international tribunal proceeded to delimit the continental shelf beyond 200nm, also known as the outer continental shelf. ${ }^{41}$ In doing so, the Tribunal was also the first to spell out the relationship between an international court and tribunal and the Commission on the Limits of the Continental Shelf (CLCS) - a technical body established under UNCLOS which deals with the establishment of the outer limits of the continental shelf. As the first international tribunal to venture into examining these important but hitherto unexplored issues, some scholars have predicted that "the ITLOS decision may prove to be influential in the context of future dispute resolution, whether through third party adjudication or not" 42 . The Bangladesh/Myanmar case therefore presents a unique opportunity to see whether ITLOS indeed managed to seize the opportunity and exert its public authority. ${ }^{43}$

41 Delimitation of the maritime boundary in the Bay of Bengal (Bangladesh/Myanmar), Judgment, ITLOS Reports 2012, para. 4.

42 Lin, S. and Schofield, C. (2014), "Lessons from the Bay of Bengal ITLOS case: Stepping Offshore for a "Deeper" Maritime Political Geography", The Geographical Journal 180(3), 260-264, 263.

43 Ghana/Cote d'Ivoire essentially follows the approach of Bangladesh/Myanmar. Thus, for the sake of simplicity, only Bangladesh/Myanmar will be mentioned in the analysis. 
While there had been some confusion relating to the use of the terms "delimitation" and "delineation",44 ITLOS made clear in Bangladesh/Myanmar that delineation and delimitation are two distinct concepts, ${ }^{45}$ and that delimitation would not depend on delineation. ${ }^{46}$ On the basis of this distinction, ITLOS clarified the much debated relationship between the UNCLOS tribunals and the CLCS. ${ }^{47}$ More specifically, ITLOS stated that, as a dispute settlement body, it has the legal expertise to interpret and apply the provisions of the Convention; while the CLCS deals with scientific and technical issues. ${ }^{48}$ ITLOS noted that there was nothing in the Convention, the Rules of Procedure of the Commission or in its practice to indicate that delimitation of the continental shelf constituted an impediment to the performance by the Commission of its functions. ${ }^{49}$ Similarly, the CLCS should exercise its technical function "without prejudice to questions of delimitation" as required under Article 76(10). ITLOS thus adopted the view that the absence of a CLCS recommendation relating to the limits of the continental shelf beyond $200 \mathrm{~nm}$ could not prevent it from determining the existence of entitlement to the continental shelf and delimiting the continental shelf between the parties concerned.

The clarification of the interrelated but independent relationship between the two institutions has a significant bearing on the temporal order in which delimitation and delineation are to be carried out. This approach stood in contrast with earlier decisions by other international

44 In the context of the outer continental shelf, "delimitation" refers to the establishment of a boundary that divides overlapping entitlements lying beyond $200 \mathrm{~nm}$ from the baselines of one or more States, whereas delineation refers to the establishment of the limits of the continental shelf. See, e.g., Macnab, R. (2004), "The Case for Transparency in the Delimitation of the Outer Continental Shelf in Accordance with UNCLOS Article 76", Ocean Development and International Law 35, 1-17; Rangel, V.M. (2006), "Settlement of Disputes Relating to the Delimitation of the Outer Continental Shelf: The Role of International Courts and Arbitral Tribunals", The International Journal of Marine and Coastal Law 21(3), 347-362.

45 Bangladesh/Myanmar, supra note 41, para. 376.

46 Ibid., paras 397-399.

47 See Kunoy, B. (2012), "The Terms of Reference of the Commission on the Limits of the Continental Shelf: A Creeping Legal Mandate", Leiden Journal of International Law 25(1), 109-130; Oude Elferink, A.G. (2004), "The Continental Shelf beyond 200 Nautical Miles: The Relationship between the CLCS and Third Party Dispute Settlement" In: A.G. Oude Elferink and D. Rothwell (eds), Oceans Management in the $21^{\text {st }}$ Century: Institutional Frameworks and Responses. Leiden: Martinus Nijhoff, 107-124, 118.

48 Bangladesh/Myanmar, supra note 41, para. 411.

49 Ibid., para. 377. 
courts and tribunals, such as Canada/France arbitration in 1992, in which the arbitral tribunal declined to recognize any rights of the parties over the outer continental shelf in the absence of a determination as to where their entitlements ended $;^{50}$ or Nicaragua $v$. Honduras in 2007 , in which the ICJ held that "any claim of continental shelf rights beyond 200 miles must be in accordance with Article 76 of UNCLOS and reviewed by the Commission on the Limits of the Continental Shelf established thereunder" 51 . After ITLOS rendered its judgment in Bangladesh/Myanmar, the annex VII arbitral tribunal in Bangladesh/India essentially the same approach and in fact, frequently referred to the ITLOS judgment. ${ }^{52}$ It is also interesting to note that the ICJ seems to have adopted the view of ITLOS in Bangladesh/ Myanmar regarding the relationship between delineation and delimitation and that between the CLCS and international tribunals. ${ }^{53}$ The 2016 Nicaragua $v$. Colombia judgment thus presented an important shift in the approach of the ICJ to the relationship between itself and the CLCS. Moreover, both Nicaragua and Colombia relied extensively on the two Bay of Bengal cases in their pleadings to advance their arguments. ${ }^{54}$ Even when Colombia urged the ICJ not to confirm jurisdiction to delimit the outer continental shelf beyond $200 \mathrm{~nm}$, it did not argue that the conclusions reached by ITLOS were wrong or unreasonable. It merely contended that the factual circumstances of the case before the Court differed substantially from those of the Bay of Bengal case, so that ITLOS' conclusions were not applicable to the case. ${ }^{55}$ This illustrates that the significance of ITLOS' decision transcended the case in which it were delivered. With the 2016 Nicaragua $v$. Colombia judgment, the approach of international courts and tribunals regarding the relationship between a dispute settlement body

50 Delimitation of Maritime Areas between Canada and France (10 June 1992) RIAA Volume XXI 265-341, [81].

51 Territorial and Maritime Dispute between Nicaragua and Honduras in the Caribbean Sea (Nicaragua v. Honduras) (2007) ICJ Rep 659, para. 319.

52 Bay of Bengal Maritime Boundary Arbitration (Bangladesh/India) (7 July 2014), paras 75, 80, available at http://www.pcacases.com/web/sendAttach/383, accessed 27 December 2017.

53 Ibid., para. 112.

54 Nicaragua v. Colombia, Written Statement of the Republic of Nicaragua to the Preliminary Objections of the Republic of Colombia (19 January 2015) paras 2.25, 2.27, 2.29, 2.31, available at http://www.icj-cij.org/docket/files/154/18780.pdf, accessed 27 December 2017.

55 Nicaragua $v$. Colombia, Preliminary Objections of the Republic of Colombia, Volume I (14 August 2014) paras 5.68, 7.16, available at http://www.icj-cij.org/docket/ files/154/18778.pdf, accessed 27 December 2017. 
and the CLCS, along with its implications on the former's jurisdiction to delimit the outer continental shelf seems to have converged.

However, the broader impact of the case should be assessed with caution. The Bay of Bengal is highly unique, in that the entire bay is covered under a thick layer of sediment, and Bangladesh and Myanmar had made their submissions to the CLCS indicating their entitlement to the continental margin extending beyond $200 \mathrm{~nm}$ based on the thickness of sedimentary rocks pursuant to the formula contained in Article 76(4)(a)(i) of the Convention. ${ }^{56}$ Therefore, it was beyond any doubt that the parties had entitlement to an outer continental shelf based on the thickness of the sediment on its floor. This enabled ITLOS to reach the conclusion that it could proceed to delimitation even when the CLCS had not issued its recommendations, which might not be feasible in other cases due to different geographical and geomorphological characteristics of the area in question.

In conclusion, the limited number of cases brought before ITLOS means its decisions may not be far-reaching in terms of the number of legal issues elucidated. However, ITLOS managed to make good use of the opportunity afforded to it and made some important contributions to clarifying the law in two areas: coastal States' power in the EEZ and the regime of the outer continental shelf. Bunkering and confiscation of fishing vessels are common practice around the world but their legitimacy had always been controversial. Thus, ITLOS' answers had an impact that was not confined to the specific case of Virginia G, but rather had a legitimizing effect and provided important guidance for States when conducting their activities at sea. As no other international courts or tribunals have dealt with these issues, ITLOS' decision remains the authority in this regard. Moreover, ITLOS was also the pioneer in examining issues concerning the legal regime of the outer continental shelf - an issue which had been avoided, or only superficially examined, by other international courts or tribunals. The fact that the ICJ in the 2016 Nicaragua v. Colombia case adopted a simi-

56 Continental Shelf Submission of the Union of Myanmar, 3, available at http://ww w.un.org/Depts/los/clcs_new/submissions_files/mmr08/mmr_es.pdf, accessed 27 December 2017; Submission by the People's Republic of Bangladesh to the Commission on the Limits of the Continental Shelf, para 6.5, available at http://www. un.org/Depts/los/clcs_new/submissions_files/bgd55_11/Executive\%20summary\% 20final.pdf, accessed 27 December 2017; The Indian Continental Shelf, Partial Submission to the Commission on the Limits of the Continental Shelf, Pursuant to Article 76, paragraph 8 of the United Nations Convention on the Law of the Sea, Appendix 1, available at http://www.un.org/Depts/los/clcs_new/submissions_ files/ind48_09/ind2009executive_summary.pdf, accessed 27 December 2017. 
lar approach to that of ITLOS, despite having refused to do so in 2012 and the lack of any reference to ITLOS' decision, provides evidence of the latter's authority.

\section{Advisory opinion}

Similar to the ICJ, ITLOS as a standing tribunal also has the jurisdiction to give advisory opinions. However, unlike the ICJ, the advisory function is only explicitly conferred on the Seabed Disputes Chamber (SDC) under Article 191 UNCLOS, not upon ITLOS as a whole. ${ }^{57}$ The SDC has exclusive jurisdiction to render advisory opinions concerning activities in the Area under Article 190 UNCLOS. The SDC exercised its advisory power in the Advisory Opinion on Activities in the Area and clarified the nature and content of sponsoring States' "obligation to ensure" over activities in the Area as found in Article 139. The Advisory Opinion on Activities in the Area will likely have an important role in the development of the Mining Code by the International Seabed Authority. The SDC's exclusive advisory jurisdiction and the significance of the Advisory Opinion on Activities in the Area mean that the authority of ITLOS in the development of the rules regulating deep seabed activities is hardly questionable.

However, as mentioned, UNCLOS only confers advisory jurisdiction to the SDC, not the full ITLOS. This has prompted the long-debated question of whether ITLOS as a full tribunal also has jurisdiction to give advisory opinions. ${ }^{58}$ ITLOS finally answered this question in the positive in the

57 Under Article 191 UNCLOS, the SDC is mandated to "give advisory opinions at the request of the Assembly or the Council on legal questions arising within the scope of their activities".

58 See, e.g., Kim, D. (2010), "Advisory Proceedings before the International Tribunal for the Law of the Sea as an Alternative Procedure to Supplement the DisputeSettlement Mechanism under Part XV of the United Nations Convention on the Law of the Sea", Issues in Legal Scholarship 11, 1; Jesus, J.L. (2006), "Commentary on Article 138 of the Rules of the Tribunal” In: P. Chandrasekhara Rao and Ph. Gautier (eds), The Rules of the International Tribunal for the Law of the Sea: A Commentary. Leiden: Martinus Nijhoff, 39; Rosenne, S. (1998), "International Tribunal for the Law of the Sea: 1996-97 Survey", The International Journal of Marine and Coastal Law 13(4) 487-514; You, K.J. (2008), "Advisory Opinions of the International Tribunal for the Law of the Sea: Article 138 of the Rules of the Tribunal, Revisited", Ocean Development \& International Law 39(4), 360-371; Ndiaye, T.M. (2010), "The Advisory Function of the International Tribunal for the Law of the Sea”, Chinese Journal of International Law 9(3), 565-587. 
Advisory Opinion on IUU Fishing in 2015. ITLOS founded its advisory jurisdiction on the basis of a combined reading of Article 288(1) of UNCLOS, Article 21 of that ITLOS Statute and Article 138 of the Rules of Procedure of ITLOS. More specifically, ITLOS held that Article 21 of ITLOS Statute, existing independently of Article 288 of the Convention, ${ }^{59}$ allows the tribunals to exercise jurisdiction over not only "disputes" and "applications" but also "all matters provided for in any other agreement which confers jurisdiction on the Tribunal"60. The words "all maters" in ITLOS's view, "must mean something more than only 'disputes" and "that something more must include advisory opinions if specifically provided for in any other agreement" 61 . ITLOS also found that "the prerequisites that need to be satisfied before the Tribunal can exercise its advisory jurisdiction" under Article 138 of the Rules were further met in that instance. ${ }^{62}$

Thus, the fact that the full ITLOS was determined to establish advisory jurisdiction arguably denotes an underlying desire on the part of the Tribunal to expand its competence and thus to increase its authority in the field of the law of the sea, despite the lack of an explicit legal basis under UNCLOS and the ITLOS Statute. ITLOS saw the advisory jurisdiction as an important opportunity for it to expand its authority beyond contentious cases, which, as mentioned, have been few and far between. The determination to assert jurisdiction despite the fierce objection from State parties to UNCLOS as demonstrated in their oral pleadings, as well as from the scholarly community, ${ }^{63}$ seems to bear out Bogdandy and Venzke's observation that international courts "are by no means interested solely in making an interesting contribution to a general discussion; rather, many decisions seem tailored toward laying authoritative premises for the future" 64 .

59 Request for Advisory Opinion submitted by the Sub-Regional Fisheries Commission (Advisory Opinion, 2 April 2015) ITLOS Reports 2015, paras 4, 52.

60 Ibid., para. 4.

61 Ibid., para. 56.

62 Ibid., para. 59.

63 Ruys, T. and Soete, A. (2016), “Creeping' Advisory Jurisdiction of International Courts and Tribunals? The Case of the International Tribunal for the Law of the Sea”, Leiden Journal of International Law 29(1), 155-176; Lando, M. (2016), "The Advisory Jurisdiction of the International Tribunal for the Law of the Sea: Comments on the Request for an Advisory Opinion Submitted by the Sub-Regional Fisheries Commission", Leiden Journal of International Law 29(2), 441-461.

64 Von Bogdandy and Venzke, supra note 8. 106. 
In terms of the substance, the questions asked of ITLOS was that relating to flag States' Similar to the Advisory Opinion on Activities in the Area, ITLOS managed to shed light on the nature of flag States' obligations over fishing vessels operating in another State's EEZ, on which UNCLOS is silent. ITLOS made an important contribution to the law on fisheries and protection of the marine environment by imposing on flag States an "obligation to"65 While ITLOS stated that the SDC's exposition of the "responsibility to ensure" in the context of recalling that sponsoring States' activities in the Area was "fully applicable in the present case", it still elaborated on the meaning of "due diligence obligation", and specified the content of this obligation and identified concrete obligations to be taken with in dealing with IUU fishing. ${ }^{66}$

Even though the obligations and measures that ITLOS spelled out may still seem general, they at least provide a minimum standard and a yardstick to assess whether the due diligence obligation has been met. The authoritative weight of ITLOS' opinion is further highlighted in light of the fact that, in contrast to other areas such as marine pollution and sea safety, there are no globally agreed minimum standards of flag State responsibilities in the fishing sector. ${ }^{67}$ In other words, even when the Advisory Opinion has no legal binding force, it "create[s] legitimate expectations and must therefore be taken in account in future decisions" 68 . In fact, in the South China Sea arbitration, which was decided by an arbitral tribunal established under Annex VII of UNCLOS, the arbitral tribunal recalled ITLOS' findings and applied the standard of due diligence as elaborated by ITLOS to the facts of the case in question in dealing with Chinese fishing vessels' alleged violations of various obligations under the Convention. ${ }^{69}$ This illustrates the impact of ITLOS' interpretation of the law, demonstrating that its exercise of public authority has reached beyond the confine of the Advisory Opinion and has become a point of reference in the legal discourse.

65 Advisory Opinion on IUU Fishing, supra note 59, para. 124.

66 Ibid., para. 125.

67 Zwinge, T. (2011), "Duties of Flag States to Implement and Enforce International Standards and Regulations - And Measures to Counter Their Failure to Do So", Journal of International Business and Law 10(2), 297-323.

68 Von Bogdandy and Venzke, supra note 8, 116.

69 South China Sea (Philippines v. China), Arbitral Award on the Merits, para. 744, available at https://www.pcacases.com/web/sendAttach/2086, accessed 27 December 2017. 
In short, by establishing advisory jurisdiction for the full tribunal, ITLOS expanded its power beyond what is explicitly provided for under the Convention. Some commentators have argued that advisory proceedings give international courts and tribunals more leeway to develop the law. ${ }^{70}$ If this is the case, ITLOS has opened a door for itself to increase its authority, albeit amidst considerable controversy. The substance of the two Advisory Opinions that ITLOS has issued have proved to be less controversial and are significant contributions to the law of the sea.

\section{Conclusion}

ITLOS was established to deal specifically with law of the sea disputes arising from UNCLOS, and was the product of a large number of developing States' dissatisfaction with and mistrust in the ICJ. The fact that ITLOS is a permanent tribunal, set up specifically to deal with the law of the sea disputes anticipates a special place for the Tribunal in the law of the sea dispute settlement scene. However, from its inception, ITLOS faced considerable scepticism regarding its capacity to act as a specialized court and its utility when operating alongside the existing ICJ. Indeed, critiques to date remain critical, pointing to the small docket of cases and the fact that the cases that make up the bulk of the Tribunal's docket have been those concerning prompt release and provisional measures. As a result, ITLOS has always struggled to prove the usefulness of its existence and its capacity. All these factors cast a negative shadow over the discussion regarding the exercise of its public authority as an international tribunal.

This paper sought to examine ITLOS' exercise of public authority using the definition of "public authority" developed by Bogdandy and Venzke. While not claiming to be completely comprehensive, it finds that ITLOS has indeed exercised different elements of public authority as defined by these authors. The Tribunal's authority over the parties to the case, ie the

70 Lachs, M. (1983), "Some Reflections on the Contribution of the International Court of Justice to the Development of International Law", Syracuse Journal of International Law and Commerce 10(2), 239-278, 249; Kateka, J.L. (2013), "Advisory Proceedings before the Seabed Disputes Chamber and before the ITLOS as a Full Court", Max Planck Yearbook of United Nations Law 17(1), 159-171, 161; Oellers-Frahm, K. (2012), "Lawmaking Through Advisory Opinions?" In: A. von Bogdandy and I. Venzke (eds), International Judicial Lawmaking: On Public Authority and Democratic Legitimation in Global Governance. Heidelberg: Springer, 69-98, 86. 
capacity to impact their behaviour, could be most prominently observed in provisional measures cases. The parties concerned complied with and were appreciative of the measures that the Tribunal prescribed in all cases, even when the measures were not what they initially requested or were subsequently revoked.

The second element of public authority, i.e. the ability to establish interpretation as points of reference for legal discourse, can be observed in the three other types of proceedings. In particular, in prompt release proceedings, ITLOS' elaboration of what constitutes "reasonable bond" furnished this crucial but vague term with meaning. The specific criteria for assessment that ITLOS continuously developed and refined in the first ten years of its existence have arguably become an authoritative point of reference and made it possible for States to have a clear understanding of their obligations, enabling them to deal with similar situations out of court. As a result, ITLOS has not received any prompt release cases since 2007. In contentious proceedings, the number of legal issues it has dealt with is admittedly rather modest. However, it should also be acknowledged that some of these had been highly controversial issues, with which ITLOS was the first international tribunal to deal with. Whatever the debate was, it is now clear from Virginia $G$ that coastal States can regulate bunkering of fishing vessels in their laws and confiscate foreign vessels fishing in their EEZ provided that such a measure is "necessary". In light of Bangladesh/Myanmar, the distinction between delimitation and delineation is evident, as is the relationship between a court or tribunal and the CLCS when it comes to delimiting the outer continental shelf. ITLOS' approach to the delimitation of the outer continental shelf was a clear departure from other courts and tribunals' previous cases, but has now seem to be taken up by other judicial bodies, including both arbitral tribunals and the ICJ. As a result, ITLOS' judgments were important in determining the direction in which the law should develop, putting an end to years of uncertainty. While ITLOS' semantic authority in the long-term ought to be assessed with caution due to the fact-dependent reasoning that the Tribunal provided, there is evidence to show that ITLOS also exercises authority over other courts and tribunals. Finally, ITLOS expanded its advisory jurisdiction beyond what is explicitly stipulated in the Convention. This decision certainly raises questions of legitimacy, but it cannot be denied that it paved the way, perhaps intentionally, for ITLOS to increase its authority in the field. In contrast, the substance of the two Advisory Opinions that ITLOS has so far rendered is much less controversial and in fact, highly welcome. The Advisory Opinions have proved to be powerful point of reference in the legal 
discourse, particularly with regard to the law on marine environment protection.

In sum, amidst the cynicism, ITLOS has shown that it can and does exercise elements of public authority in the field of the law of the sea. While limited in magnitude, ITLOS' judgments have the capacity to influence the behaviour of States and other judicial bodies, and serve as the reference point in the legal discourse, at least with regard to issues concerning coastal State's power in the EEZ and the outer continental shelf regime. 
